
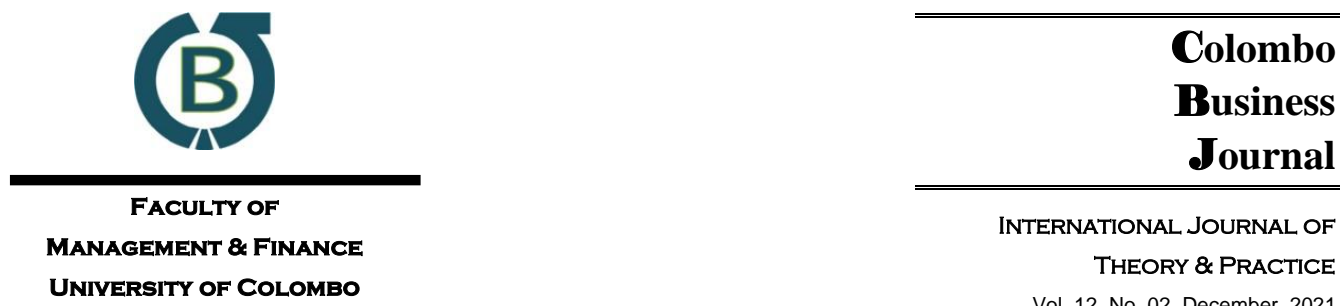

INTERNATIONAL JOURNAL OF

THEORY \& PRACTICE

Vol. 12, No. 02, December, 2021

\title{
The Men's Marriage Premium in the United States: What \\ Remains after Controlling for Publication Bias and Heterogeneity?
}

\author{
Nuwan Indika Millagaha Gedara $\bowtie$ \\ Department of Economics, Kansas State University, USA
}

\begin{abstract}
Married men earn more than single men, which is a significant finding in labour and family economics. A considerable amount of research literature discusses this estimated wage effect for married men in the United States. This study finds a meaningful impact on wage after controlling for the publication bias with heterogeneity, a considering meta-analysis of 120 estimates. Marriage premium accounts for $6.8 \%$ compared to unmarried men with the evidence of publication bias after applying descriptive statistics, funnel graph, simple metaregression analysis (MRA), and multiple MRAs. Also, this analysis identifies omitted variable bias as another important aspect for explaining this widespread empirical literature.
\end{abstract}

Keywords: Publication Bias, Meta-analysis, Marriage Wage Premium, Meta-regression Analysis

$\begin{array}{lll}\text { Received: } & \text { Accepted revised version: } & \text { Published: } \\ \text { 20 January 2021 } & \text { 07 September 2021 } & \text { 31 December } 2021\end{array}$

Suggested citation: Millagaha Gedara, N. I. (2021). The men's marriage premium in the United States: What remains after controlling for publication bias and heterogeneity? Colombo Business Journal, 12(2), 53-79.

DOI: http://doi.org/10.4038/cbj.v12i2.82

(C)2021 The Authors. This work is licensed under a Creative Commons Attribution 4.0 International License which permits unrestricted use, distribution, and reproduction in any medium, provided the original work is properly cited.

$\triangle$ mgnindika@dbe.cmb.ac.lk (iD) https://orcid.org/0000-0002-9862-8685 


\section{Introduction}

Married men earn more than single men, which is a significant finding in labor and family economics. That premium indicates a $10 \%$ and $40 \%$ premium when considering the studies in the early 1970s and 1980s. However, researchers find this marriage premium diminishing over time. Some argue reducing $20 \%$ from 1968 to 1988 (Blackburn \& Korenman, 1994), but some said it fell from 11\% in the late '70s to $6 \%$ in the early 90 's. When considering the literature, we can find that the premium has grown, decreased, or remained constant over time. As a result, it is possible that this marriage premium has not been fully captured or estimated by previous studies.

There are two main theories can be identified to explain this wage premium. The first theory (specialization) is that marriage makes a man more productive through intra-household specialization between husbands and wives (Becker, 1981; Korenman \& Neumark, 1991; Chun \& Lee, 2001; Lerman, 2002; McConnell \& Valladares-Esteban, 2021). The second theory (selection) implies that men who possess certain attributes, people skills, and personal characteristics would be considered more attractive in the marriage and labor markets (Nakosteen \& Zimmer,1987, 1997; Ginther \& Zavodny, 2001; Ludwig \& Brüderl, 2018, Indika, 2018). However, these skills and attributes are unobservable but correlated with wages. Thus, this theory does not imply that marriage increases the unobservable skills, but unobservable skills impact marriage selection. This implies that men with higher earnings are more likely to get married than single men. This explanation is not as well supported in the literature as the specialization concept. However, it does express the importance of controlling for other characteristics related to wage earnings when comparing the wages of men in different relationship status (whether they be single, divorced, or married).

Identifying whether and how much marriage is a cause or simply an effect of men's higher earnings is a complicated problem. Thus, studies consider the different types of variables and different types of models to capture this unclear marriage premium. For example, most studies have included different types of variables (for example, years of marriage) and used different models (fixed effect/random effect) to capture this premium; however, some studies do not consider these factors and they are not concerned about the statistical behavior, rather, they are concerned with how their papers get published (Stanley, 2001). Therefore, this study investigates how those omitted variable biases affect the men's marriage premium and correct the magnitude of reported marriage premiums for publication biases. Moreover, this research is conducted to find better ways to understand the marriage premium and minimize the conflicting results. These phenomena can be identified using the meta- 
regression analysis (MRA) to correct the magnitude of reported marriage premium for their publication biases. The main contribution of this study is to use the empirical application of meta-regression analysis by using meta-data while employing techniques of descriptive statistics, funnel graph, simple meta-regression analysis (MRA), and multiple MRAs and correcting the magnitude of reported marriage premium for their publication biases. I found that the marriage premium accounts for $6.8 \%$, with evidence of publication bias. Once these biases are filtered out with heterogeneity, there exists a meaningful impact on marriage premium for men from United States of America (US). Also, this analysis identifies omitted variable bias as another essential aspect for explaining this widespread empirical literature. The paper is organized as follows; Section two discusses dominant theories for the male marriage premium; Section 3 describes the meta-data. Section 4 depicts the metaregression analysis using meta-data by employing descriptive statistics, funnel graphs, simple meta-regression analysis (MRA), and multiple MRAs. Section 5 contains the conclusions.

\section{Theoretical Background}

This section discusses the dominant theories, ideas, and causes of the male marriage premium, considering the general method of estimating the marriage premium.

\section{The Theory of Specialization}

Two main theories can be identified to explain this wage premium. The first theory can be discussed as the theory of specialization. This theory is recognized by Becker (1981), finding that productivity is the key factor for differences between married and unmarried men. The productivity approach suggests the role of traditional household specialization or labor division by gender. Nobel laureate Gary Becker is one of the key persons to discuss this household specialization or productivity hypothesis. Becker suggests that productivity is the key factor for the difference in the wage premium between married and unmarried men. Becker suggests that our efficiency in doing day-to-day activities depends on the amount and type of "human capital" people possess (skills, appearance, reputation, credentials, experience, and knowledge). Becker defined this human capital in two parts: household-related capital and market-related capital. This human capital knowledge increases his/her productivity and has an impact to increase his/her wage.

Moreover, married partners can take advantage of this human capital investment to be more productive in home production and market-related activities. For example, 
men have a small comparative disadvantage of housework and childbearing, but a small labor advantage. Thus, wives influence housework efficiency, and husbands can focus on the labor market with their comparative advantage. So, it is clear that starting with this small advantage as a division of labor can become a large advantage over time as married partners. Therefore men who never marry have to specialize in household and labor market activities using more time and energy. It is a disadvantage for them compared to married men. This specialization incorporates the women's effect on married men gaining more energy that can be used to work more productively. So, it allows married men to increase their wages in advance (Becker 1981). Hersch and Stratton (2000) test the specialization hypothesis and find that the wage premium is not considerably affected after controlling for the home production activities using panel data from the National Survey and Households. Married men only spent $45 \%$ on traditional women's tasks, while earlier married men spent $63 \%$ and men who never married spent $61 \%$ on these tasks. Moreover, some studies find that women's labor force participation may negatively impact men's earnings (Gray 1997, Chum \& Lee, 2001, Korman \& Neumark, 1991). Also, McConnell and Valladares-Esteban (2021) identify a positive relationship between marriage and the wages of men and this finding rely on the idea that married men are focused on the labor market and their wives specialize in housework.

\section{The Selection Hypothesis}

The selection hypothesis is the second theoretical explanation for the marriage premium to understand the difference between married and never-married men. The selection theory implies that men possessing attributes like people's skills and personal characteristics would be more attractive in the marriage and labor markets. However, these skills and attributes are unobservable but correlated with wages. Thus, the theory does not imply that marriage increases unobservable skills, but unobservable skills impact the likelihood of getting married. This explanation is not as well supported in the literature as the specialization concept. However, it expresses the importance of controlling for other characteristics related to wage earnings when comparing men's wages in different relationship statuses (whether they be single, divorced, or married). Thus, researchers expect these personal characteristics to represent a group of married men with positively correlated wages compared to a group of single men.

Nakosteen and Zimmer (1987) find that men who have higher earnings are likely to select their mate. They estimate wage determinants that permit endogenous selection of marital status by using the Michigan Panel Survey Income Dynamics. 
Ginther and Zavodny (2001) propose that the wage premium due to the selection effect indicates only about $10 \%$ of the premium. Moreover, men with higher incomes are less likely to divorce than those with lower wages (Nakosteen \& Zimmer, 1997). Ginther and Zavodny (2001) estimate the marriage premium by using two types of marriages: one indicates a married man without a premarital conception, and the other is premarital conception. It indicates higher wage men are more likely to get married, and they conclude that the selection hypothesis plays a significant role in marital status. Using the non-parametric matching method, Indika (2018) finds that higherincome men are more likely to get married. The significant marriage premium accounts for $6.4 \%$ after controlling unobserved heterogeneity. Also, Ludwig and Brüderl (2018) reveal the selection hypothesis using National Longitudinal Survey of Youth (NLSY) data and find that men on a steep career track are especially likely to marry than single men.

\section{Alternative Views on Men's Marriage Premium}

A variety of explanations and reasons have been associated with increased married men's wages other than the specialization and selection hypothesis. Marriage increases earnings because of an increase in their aspiration, by stabilizing men's lives (Ahituv \& Lerman, 2007). One of the common observations is that employer discrimination or bias may impact married men to earn higher wages. Employers give married men the first choice through promotions after considering that a married employee requires more money to meet family life's financial needs. However, social ideas have been changed in the United States. Blackburn and Korenman (1994) explained the marriage premium decreased by $10 \%$ over time because of the change in employer bias's social norms.

Hamermesh and Biddle (1994) identified that physical appearance affects wages, meaning that more attractive employees get higher wages (beauty, health). They identified this by considering plain people, average-looking people, and good-looking people. As a result, beauty leads to higher earnings. Physical attractiveness is generally associated with selecting a mate and indirectly leads to a positive effect on wages.

The following factors that can influence a man's success in his career and marriage are: personal characteristics (self-esteem, extraversion, neuroticism) or social skills (communication, conflict resolution), physical appearance, education, age, etc. However, unobservable factors can impact personal life (especially marital success) rather than professional life, but unfortunately, those factors cannot be 
observed. It is clear that employers can be considering observable factors to evaluate the men, and those characteristics can be associated with married men and lead to a higher wage. .However, if the marriage fails (divorced or separated), those people's wages remain high. This can explain why divorced people earn higher than never married people because, at the time of marriage, men settle down and practice a more solid lifestyle (Chiodo \& Owyang, 2002).

Matters (2005) explained that married partners earn more money with partnerships, and it makes the couple more economically efficient because of the social norms, wealth accumulation, and productive behavior that gives them an advantage. Moreover, married partners could also receive wealth transfers (i.e., dowry) from family members that cohabiting couples or never-married people would not receive. Married couple have more stable personal routines (sleep and diet), which also help increase wages. Married men are less likely to be fired or quit without a new job in hand than with a new job compared to unmarried men (Gorman, 1999). McManus and DiPrete (2001) point out that marital status is a critical determinant when considering the welfare state tax and transfer policy. The majority of married partners paid lower federal income taxes than never-married persons in the mid1990s. It negatively impacts low-income men with loss of benefits (for example, not being qualified for food stamps ). McDonald (2020) find that married men are more likely to be invited for a job interview and receive slightly higher wages than single men.

\section{Meta-Data}

According to a systematic review of the marriage wage premium, I investigated the empirical estimation based on Google Scholar using keywords such as "men's marriage premium", and "men's wages". To be included for meta-analysis, each study was individually reviewed for its empirical estimate of wage premium with criterion's such as (i) having at least one empirical estimate of the effect of men's marriage premium.; (ii) how researchers presented their empirical findings because some did not mention independent variables for models using different estimation techniques (some only referred to the premium with marriage status: married, divorced, widowed, and never married; thus, it is hard to identify omitted variables for each model); (iii) standard errors or t-values should report coefficient of marriage premium (iv) studies that are primarily concerned about the marriage-wage premium otherwise, marriage is a common explanatory variable in wage regressions, such as wage differentials, occupational segregation, and other areas in labor economics; (v) 
regressions included married men only in the United States and not considered women. This process identified the 19 papers (See appendix 1 for selected papers with their citations) containing 120 estimates of the marriage wage premium along with sufficient information needed to estimate the meta-analysis, such as omitted variables and calculated t values (most $t$ values are not mentioned with their standard errors). These factors are important to identify and estimate potential reporting bias or publication selection bias (Egger et al., 1997; Stanley, 2008). Appendix 2 included the independent variables (coded as 45 variables) that were considered for an estimate in the meta-analysis. Those independent variables are evaluated under different scenarios like estimation techniques (e.g., fixed-effects, random-effects or OLS, methods), types of data, time period, measurement of the dependent variable (e.g., natural log or not, hourly wages), job characteristics, spouse job characteristics, and other demographic characteristics ( e.g., urban vs. rural, education level, ethnicity, religion, veteran etc.).

\section{Meta-Regression Analysis (MRA)}

Meta-analysis is characterized as a quantitative literature review (Stanley, 2001), and it is an attempt to investigate and explain the literature about some important parameters (Stanley \& Jarrell, 1989). It can help to identify the variation from study to study among empirical findings by explaining the evidence of certain questions that emerge in the findings that are contradictory or overstated.

"Meta-regression analysis is a form of meta-analysis especially designed to investigate empirical economics research" (Stanley, 2001, p.131).

MRA is a type of systematic review that uses statistical techniques to investigate and summarize in-depth, the empirical findings of the researchers. Further, metaregression analysis helps to identify the particular type of model or methods, design, and data that affect the empirical findings. Meta-regression has been successfully applied to different fields such as social and medical sciences (economics, biology, environment, etc.). Some prominent examples of meta-analysis in economics appear in Table 1. For example, Stanley and Doucouliagos (2007) applied the metaregression method to 75 empirical estimates from the efficiency-wage literature. After correcting for publication selection bias, they estimated the wage elasticity of output as 0.32 , which is smaller than what the neoclassical version of the efficiency wage hypothesis demands. 
Table 1: Selected Literature for Meta-analysis in Economics

\begin{tabular}{ll}
\hline Authors & Subject \\
\hline Stanley and Jarrell (1989) & Introduction to meta-regression analysis \\
Jarrell and Stanley (1990) & Union wage premiums \\
Smith and Kaoru (1990) & Recreation benefits \\
Weitzman and Kruse (1990) & Profit sharing and productivity \\
Phillips (1994) & Education and productivity \\
Button (1995) & Transportation benefits \\
Card and Krueger (1995) & Minimum wage effects \\
Phillips and Goss (1995) & Taxes and local development \\
Button and Kerr (1996) & Urban traffic congestion \\
Espey (1996; 1998) & Gasoline demand elasticities \\
Loomis and White (1996) & Benefits of endangered species \\
Doucouliagos (1997) & Demand for Australian labor \\
Baaijens, Nijkamp and Montfort (1998) & Regional multipliers \\
Stanley and Jarrell (1998) & Gender wage gap \\
Stanley (1998) & Tests of Ricardian Equivalence \\
Ashenfelter et al. (1999) & Returns to education \\
Stanley (2000) & Tests of The Lucas Critique \\
Gorg and Strobl( 2001) & Multinational companies and productivity \\
Doucouliagos and Ulubasoglu (2006) & Economic freedom and economic growth \\
Rose and Stanley (2005) & Common currencies on international trade \\
Stanley and Doucouliagos (2007) & Efficiency wage \\
Disdier and Head (2008) & Bilateral trade \\
Card et al.(2010) & Labor market policy \\
\hline
\end{tabular}

Source: Stanley (2001) and updated by the author- http://ideas.repec.org/k/metaana.html

\section{Meta-Analysis}

It is important to identify descriptive statistics with a simple graphical explanation for the marriage wage premium. The positive elasticity on a marriage dummy variable employed in the wage equation has become the norm in labor economics.

Figure 1 reflects the marriage premium in terms of elasticities, and the average marriage wage premium for this selected empirical literature is $0.10(10 \%)$. The smallest wage premium accounted for is -0.69 , and the maximum is 0.93 , with a deviation of 0.19 . Thus, there is a need to explain this variation in estimated and reported marriage premium to verify that the overall impression is robust. However, it is a common practice for researchers to adjust this coefficient until they arrive at the expected estimation results, otherwise, Journal editors and referees will discount papers that do not find statistical significance in the expected direction (de Linde Leonard \& Stanley, 2015). 
Figure 1: Distribution of Meta-Data on Marriage-Wage Premiums

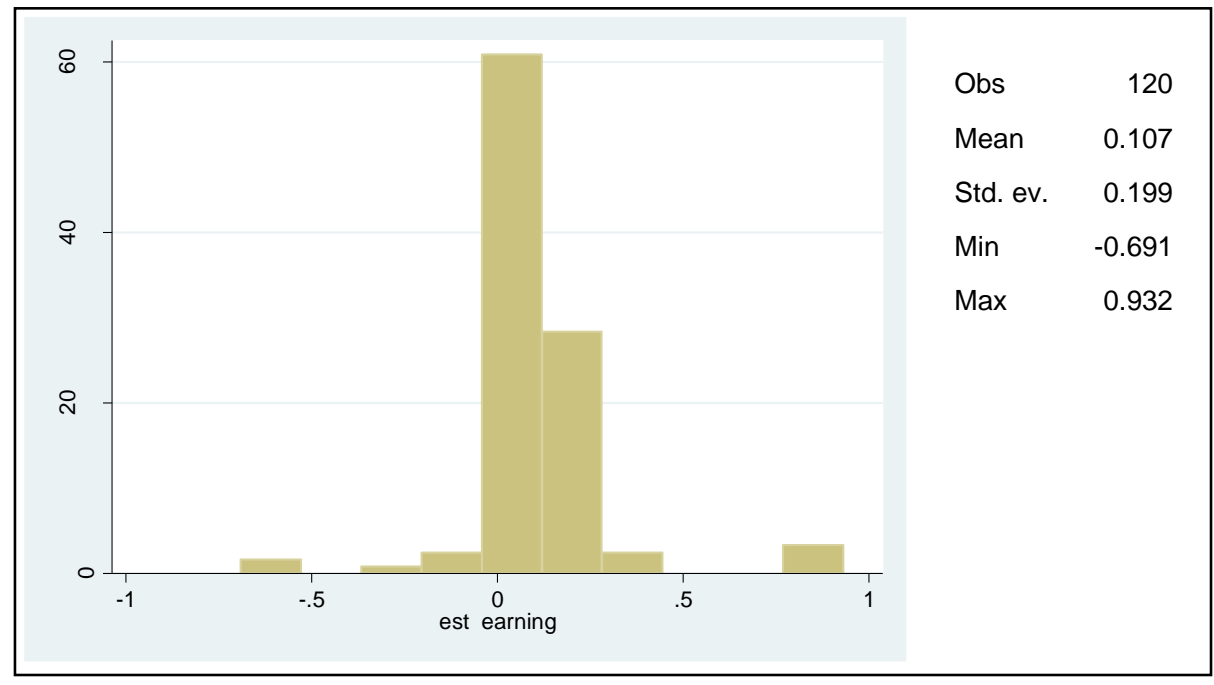

\section{Detecting the Publication Bias}

Publication bias is one of the major concerns for meta-analysis because editors, researchers, and reviewers are very concerned about the statistical significance of empirical results, leading to publication bias. Moreover, they are not concerned with insignificant results in publications most of the time (Doucouliagos \& Stanley, 2012; Doucouliagos et al., 2012). Card and Krueger (1995) explain that publication bias can exist in three ways:

1. Reviewers and editors may be predisposed to accept papers consistent with the conventional view.

2. Researchers may use the presence of a conventionally expected result as a model selection test.

3. Everyone may possess a predisposition to treat "statistically significant" results more favorably" Card and Krueger (1995, p.239).

All three publication bias instances may impact the literature to become quite skewed, and distort usual empirical findings (Stanely, 2005). Publication bias has become a common problem in most fields, including social sciences, medical research, and economics.

Stanley (2005) explains that promotion, tenure, and compensation are mostly affected by publication record in economics. This is because the structure of academia often considers the quantity of publications that researchers publish. As a result, it badly affects the young economists because they quickly learn to produce 
publications by considering statistical significance. It is clear that identifying the publication bias is very important to measure the marriage wage premium's correct magnitude elasticity. Further, finding a meaningful marriage premium after controlling for publication bias is significant to test the accurate meta-regression analysis.

The funnel graph is a widely used method to identify the publication bias. The funnel graph is a scatter diagram representing the precision vs. estimated effect such as regression coefficient, partial correlation coefficient, or elasticity. This study uses the estimated marriage wage premium and its standard errors (precision) to estimate the funnel graph. The best precision estimation is an inversion of the standard error (1/Se) (Egger et al., 1997; Stanley, 2005). One common way to detect this publication selection bias by using graphical behavior, is through a funnel approach. If there is no publication bias, then estimates should vary in a normal distribution around the estimated coefficient.

Figure 2: Funnel Plot for Estimated Marriage Wage Premium (n=120)

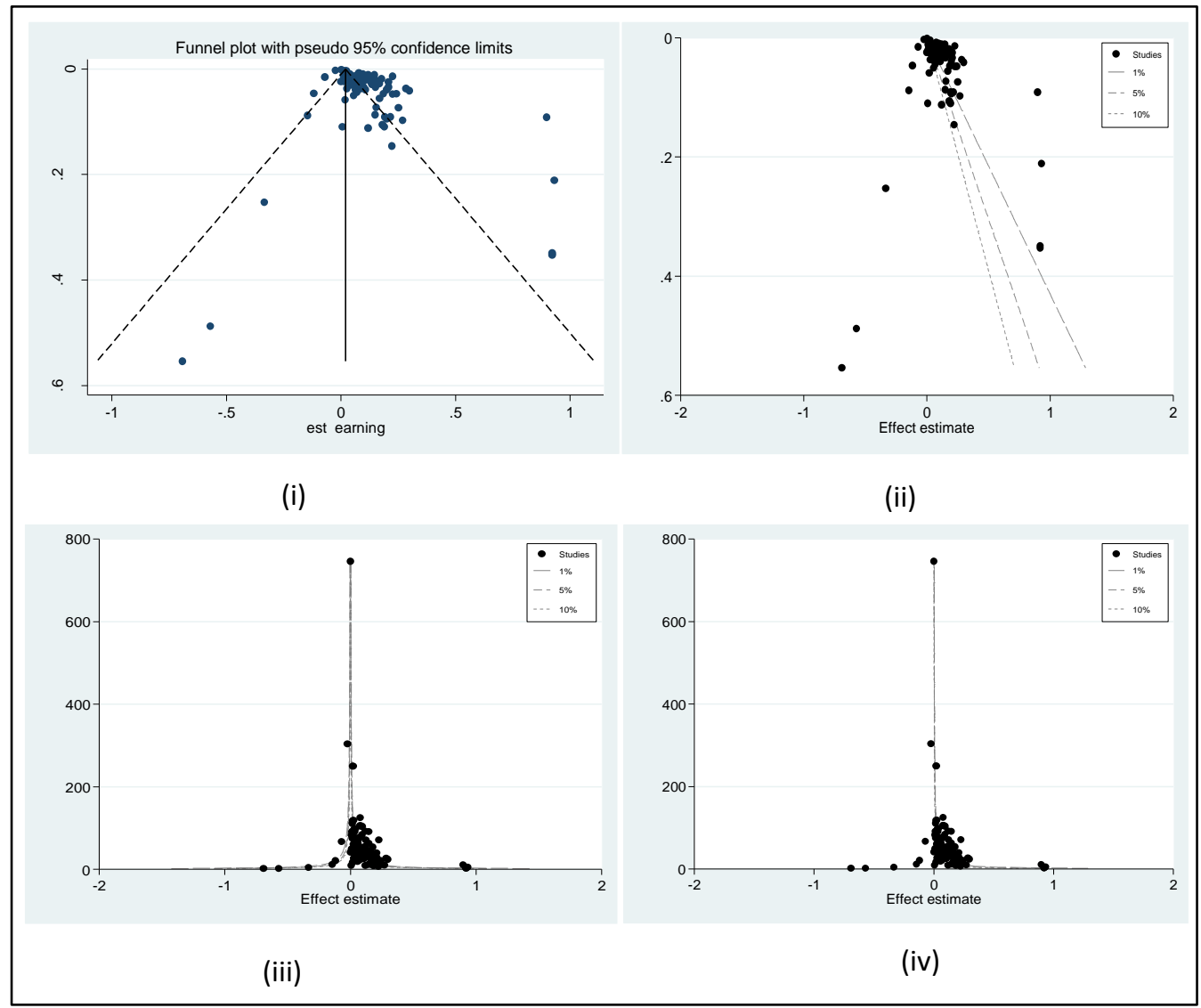


Figure 2 shows the funnel graph for the marriage wage premium. It clearly shows a strong suggestion of asymmetry in the funnel, and it shows that studies are missing on the left-hand side of the plot of publication selection. Panel (i) is where standard errors of estimated wage premium are indicated on the $\mathrm{Y}$-axis and wage premium estimates on the X-axis. Panel (ii) is similar to Panel (i) but based on one-sided pvalues. Panel (ii) clearly shows a positive bias because there is a greater spread of estimates to the right of the mean (0.01), which demonstrates there are "missing" studies to the lower left of the mean. On the other hand, the top Panels indicate a concentration of more precise estimates near the mean with missing empirical studies in the mid-range values. Panel (iii) is where inverse of standard errors of estimated wage premium are indicated on the $\mathrm{Y}$-axis and wage premium estimates on the $\mathrm{X}$ axis. Panel (iii) is similar to Panel (iv) but based on one-sided p-values. Panel (iii)indicates the smaller sample, which is less reliable and spread out, on the other hand, Panel (i) shows tightly dispersed coefficients. It is more reliable because it has a low standard error. Pannel (iv) is over-weighted on one side of the plot, which provides evidence of publication selection.

\section{Meta-Regression Analysis of Publication Bias: FAT-PET}

When reviewing the graphical analysis used to detect the publication bias, unfortunately, it is weak to subjective interpretation. However, there is a simple way to detect publication bias using statistical modeling. It involves the simple metaregression analysis between the reported effect (e.g., estimated wage premiumpartial correlation, etc.) and its standard error (Egger et al., 1997; Stanley, 2005; Stanley 2008). For example, Egger et al. (1997) use the linear approximation to test the publication bias using the reported effect and its standard error.

Effect $_{i}=\beta_{0}+\beta_{0} S e_{i}+e_{i}$

The Equation 1 indicates the estimation technique, where effect $t_{\mathrm{i}}$ is the estimated marriage wage premium coefficient in study $i, S e$ (represents the publication bias) is its estimated standard error (overall average effect corrected for publication bias), and there is also a stochastic error term. The estimated $E_{f f e c t}$ varies from study to study and randomly around the 'true' effect, $\beta_{0}$. In contrast, the publication bias correlate with the standard error ( $S e$, see Stanley, 2008). The funnel-asymmetry test (FAT) is the most convenient way to detect publication bias. It can be detected by testing hypothesis- $\mathrm{H}_{0}: \beta_{1}=0$ (Egger et al., 1997; Stanley, 2008). On the other hand, testing the null hypothesis of $\mathrm{H}_{0}: \beta_{0}=0$ indicates a valid, genuine empirical effect (precisioneffect test (PET)) remaining after the control for reporting bias is removed (Stanley, 
2008). However, if the empirical estimates and model specifications are based on the significance of the main covariates, publication bias will differ with the standard error. Moreover, larger and smaller standard error values are associated with larger estimated effect sizes and smaller effect sizes. Thus it implies that the estimated effect varies from estimate to estimate; thus, it contains heteroskedasticity in Equation 1. It is suitable to divide Equation 1 by the standard error and estimated by Weight Least Squares (WLS) (Egger et al., 1997; Stanley, 2005). We can estimate Equation 1 by dividing with precision $(1 / \mathrm{Se})$ used as weights. More precise estimates are given greater weight to correct the heteroskedasticity, or we can implement either by using a WLS routine with $1 / S e_{i}^{2}$ as the weight.

$t_{i}=\beta_{0}+\beta_{1}\left(1 / S e_{i}\right)+v_{i}$

where $t_{i}$ is the conventional $t$-statistic for the $i^{\text {th }}$ observation for the estimated marriage wage premium, the independent variable of standard error becomes the inverse $1 / S e_{i}$ precision, and $v_{i}$ is a heteroskedasticity-corrected error term. It is important to understand the intercept and slope coefficients are reversed from the OLS version in, Equation 1. As a result, testing of $\mathrm{H}_{0}: \beta_{1}=0$ is the precision-effect test (PET) that tests genuine empirical effect beyond publication selection bias. On the other hand, $\beta_{0}=0$ is evidence of publication selection (Egger et al., 1997). This test is known as the funnel-asymmetry test (FAT), which indicates marriage premium after correcting for publication selection.

Table 2 shows the results of this FAT-PET-MRA in Columns 1 and 2 for the estimated marriage premium. The estimation of FAT-PET-MRA in Equation 2 consists of three types of estimation techniques: robust standard errors, standard errors adjusted for data clustering, or robust regression.

The clustering method's estimation is important because of the multi-level nature of the data (or within studies for estimates). On the other hand, a robust regression corrects for the effects of influential outliers. The results are consistent without a robust regression estimation technique for PET. However, all the estimation techniques confirm the significantly positive funnel asymmetry (FAT) with the evidence of publication bias $(p<0.01)$, while the precision effect test shows a significantly positive empirical effect of estimated marriage premium only for the robust regression estimation technique $(t=3.79 ; p<.01)$. However, previous evidence has found that the wage benefit of marriage is unbiased with a $11 \%$ marriage premium (de Linde Leonard and Stanley, 2015). The results confirm the 
presence of average male marriage premium as approximately $2.2 \%(0.022)$, at least from the perspective of this entire research literature.

Table 2: Estimate of the FAT-PET MRA (Eq. 2) and PEESE (Eq.4) for Publication Selection

\begin{tabular}{|c|c|c|c|c|c|}
\hline \multicolumn{4}{|c|}{ FAT-PET-MRA (Equation 2) } & \multicolumn{2}{|c|}{ PEESE (Equation 4) } \\
\hline $\begin{array}{l}\text { Regression } \\
\text { /s.e. }\end{array}$ & $\begin{array}{l}\text { (1) FAT } \beta 0=0 \\
\text { Funnel } \\
\text { asymmetry }\end{array}$ & $\begin{array}{l}\text { (2) PET } \beta 1=0 \\
\text { (1/Se) } \\
\text { Meta-average }\end{array}$ & $\mathbf{N}$ & Intercept (Se) & $(1 / \mathrm{Se})$ \\
\hline Robust s.e. & $3.488161(9.55)^{* * *}$ & $0.00000847(0.00)$ & 106 & $8.436659(2.00)^{* *}$ & $0.0188602(1.77)^{*}$ \\
\hline $\begin{array}{l}\text { Clustered } \\
\text { s.e. }\end{array}$ & $3.488161(7.29) * * *$ & $0.00000847(0.00)$ & 106 & & \\
\hline $\begin{array}{l}\text { Robust } \\
\text { regression }\end{array}$ & $2.283564(5.61) * * *$ & $0.0220991(3.79)^{* * *}$ & 106 & & \\
\hline
\end{tabular}

Notes: 1 . The dependent variable is the conventional $t$ value. The brackets hold $t$-ratios, using robust standard errors, clustered standard errors, or robust regression, respectively. $\mathrm{N}$ is the number of observations. FAT measures the degree of publication bias. PET measures the effect of aid on growth corrected for publication bias. Equation 2 is estimated by using robust standard error.

2. *,** and $* * *$ denote $p<.1, p<.05$ and $p<.01$ respectively

3. R-squared in the WLS method indicates $41 \%$ of FAT-PET-MRA and $19 \%$ of PEESE

Figure 3: Egger's Publication Bias Plot

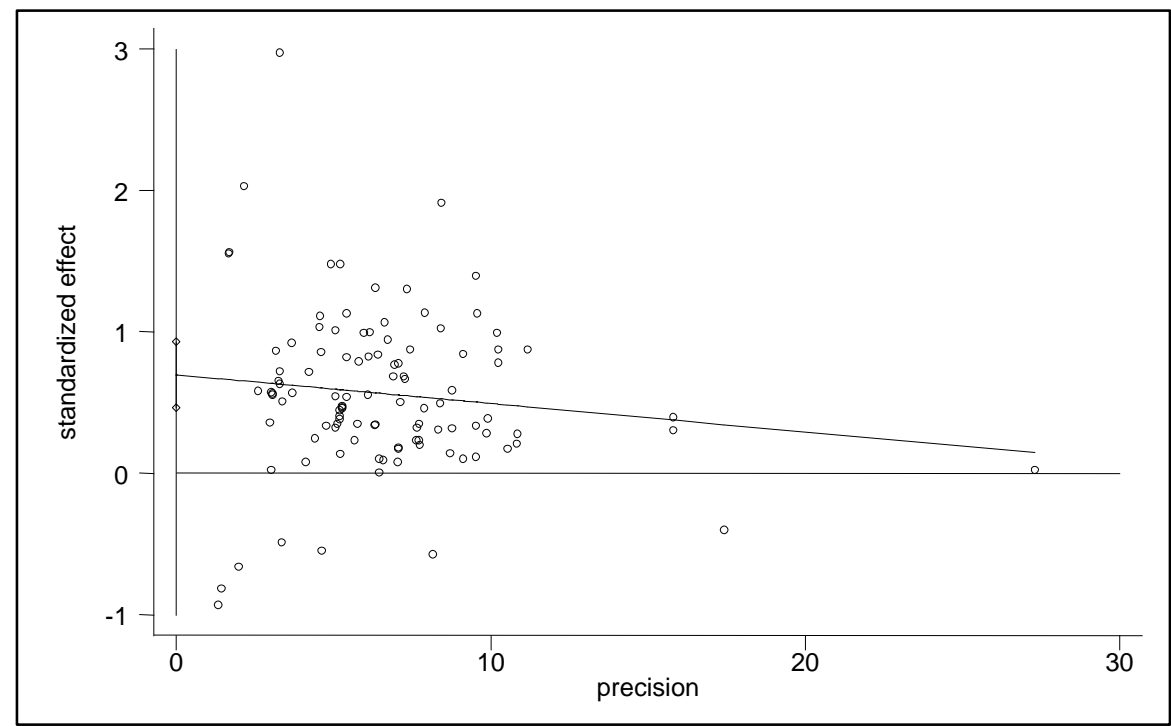

Figure 3 shows the graphical illustration of selection bias using the Egger publication plot method. To identify the publication bias, we can check the 
relationship between the effects and their standard errors. The absence of publication bias implies no relationship (upward or downward) between aid-growth effects and standard errors. However, the graph indicates the negative association or downward sloping between standardized effects, and it presents evidence of publication bias.

\section{Correcting Publication Selection-PEESE}

When considering the above-estimated results, I have discussed how the publication bias can be detected by using graphs and equations to identify the genuine empirical effect. Furthermore, another important estimation technique can be identified to correct this publication bias because policymakers and researchers need to estimate the correct magnitude of the underlying effect. Equation 2 can be identified to present a linear relationship between an estimate and its standard error. However, if there is a genuine empirical effect, $\beta_{1}$ can be biased downward (Stanley, 2008). As a result, the association between the observed effect and standard error will be nonlinear for the existence of publication bias. This estimated technique is known as a precision effect estimate with standard error (PEESE). Usually, this nonlinear relationship estimate is found by using a power series. It can estimate by adding a square of standard error (the variance of each estimated marriage wage premium) in Equation 2 or by using the WLS estimate to correct the obvious heteroskedasticity in Equation 3 or 4.

$$
\begin{aligned}
& \text { Effect }_{i}=\beta_{0}+\beta_{1} S e_{i}^{2}+\varepsilon_{i} \\
& t_{i}=\beta_{0} \text { Se }_{i}+\beta_{1}\left(1 / S e_{i}\right)+v_{i}
\end{aligned}
$$

The estimated $\beta_{1}$ of Equation 4 is the value of the marriage premium corrected for publication selection (called the 'precision-effect estimate with standard error' (PEESE)), and there is no intercept. The estimation of PEESE is found in columns 5 and 6 of Table 2 . The coefficient on precision $(1 / S e)$ is 0.019 , and it indicates a PEESE estimate of the married wage premium after correcting for the publication bias. Thus, the overall marriage premium is approximately $1.9 \%$.

\section{Funnel Graph and Trim-and-Fill Mean Estimates}

There is another method that can be used to correct the mean for publication bias. It is the trim and fills procedure suggested by Duval and Tweedie (2000). The STATA command "metatrim" can be used to correct the publication bias, which is used as an iterative algorithm to fill and recompute the mean effect size by adding missing values in the data until the observations are symmetric. 
Table 3: Trim-and-Filled Meta-Analysis

\begin{tabular}{clllc}
\hline Trimming estimator & & & & \\
\hline Iteration & Estimate & Tn & \# to trim & diff \\
\hline 1 & 0.02 & 4969 & 40 & 5671 \\
2 & 0.012 & 5096 & 43 & 254 \\
3 & 0.011 & 5099 & 43 & 6 \\
4 & 0.011 & 5099 & 43 & 0
\end{tabular}

Filled

\begin{tabular}{llllrr}
\hline \multirow{2}{*}{ Method } & Pooled Est & \multicolumn{2}{c}{ 95\% CI } & \multicolumn{2}{c}{ Asymptotic } \\
\cline { 3 - 6 } & & Lower & Upper & $z_{-}$value & $\boldsymbol{p}_{-}$value \\
\hline Fixed & 0.011 & 0.01 & 0.013 & 12.137 & 0.000 \\
Random & 0.026 & 0.014 & 0.038 & 4.142 & 0.000 \\
\hline
\end{tabular}

Notes: 1 . Test for heterogeneity: $Q=3642.452$ on 148 degrees of freedom $(p=0.000, N=149)$

2. Moment-based estimate of between studies variance $=0.004$

Figure 4: Filled Studies from Metatrim

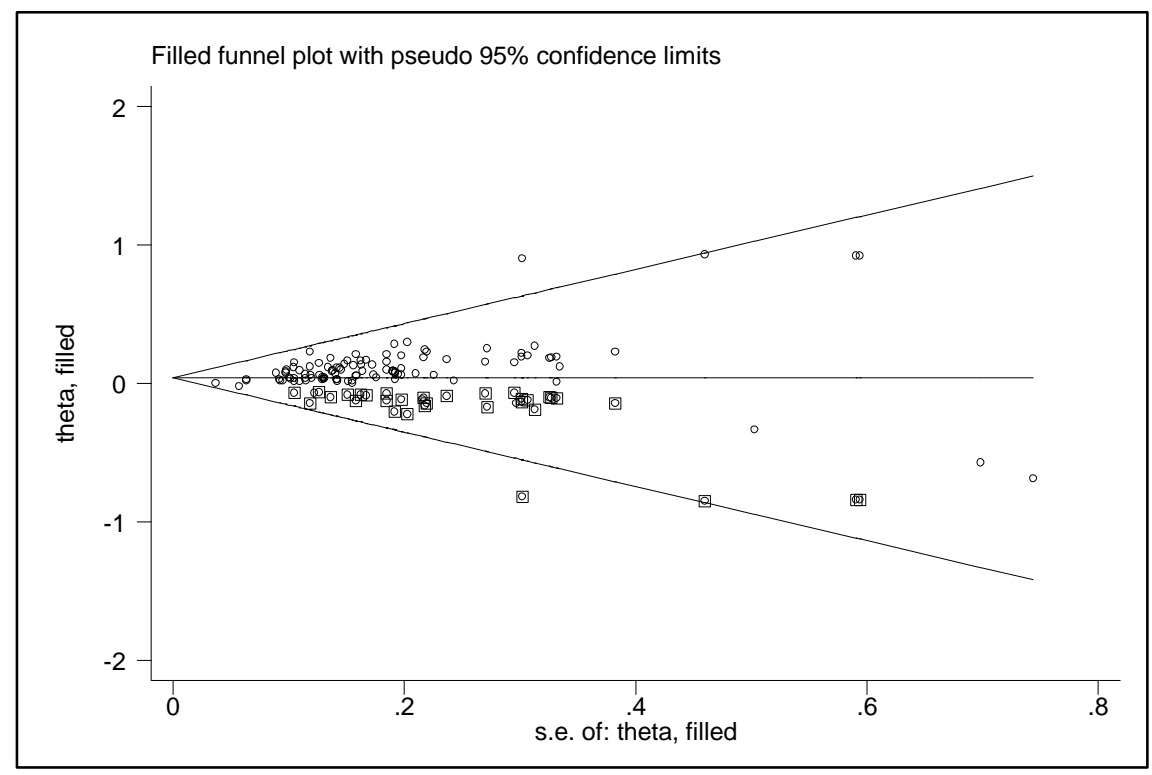

Table 3 indicates that the fixed effect of mean 0.011. Compared to the PEESE method, the trim-and-fill estimation technique reduces the mean estimation by $0.8 \%$. Furthermore, the conventional Q-test clearly shows excess heterogeneity $(\mathrm{Q}=$ 3642.452; $\mathrm{df}=148 ; p<0.001)$. Figure 4 shows the trim and fill method of the studies after correcting for the missing studies, which are in the region of $p<0.05$ confidence limits. 


\section{Multivariate MRA with $Z$ and $K$ Variables}

The most important thing about these meta-regression analyses for publication bias is heterogeneity. Most of the research is easily affected by this heterogeneity even after they controlled the publication bias. Meta-analyses have found that, lot of choice variables, different model techniques, and different data can be used for metaregression analysis. However, those can highly impact a practical difference in reported research results because of publication bias and heterogeneity. On the other hand, MRA's coefficient can be biased when important factors are omitted. As a result, it is necessary to identify the best strategy to detect this publication bias with heterogeneity.To identify potential marriage wage premium with publication bias: the simple MRA Model 2 can be greatly expanded by including moderator variables, $Z_{k}$, that explain variation in estimated marriage premium and other factors (omitted variables), $K_{j}$, that are correlated with the publication bias process itself.

$$
\begin{aligned}
& \text { Effect }_{i}=\beta_{0}+\alpha_{0} S e_{i}+\sum \beta_{k} Z_{k i}+S e_{i} \sum \alpha_{j} K_{j i}+\varepsilon_{i} \\
& t_{i}=\alpha_{0}+\beta_{0}\left(1 / S e_{i}\right)+\sum \beta_{k} Z_{k i} / S e_{i}+\sum \alpha_{j} K_{j i}+v_{i}
\end{aligned}
$$

Moreover, the variable, $Z$ explains the heterogeneity in the true estimates wage premium and misspecification biases (genuine empirical effect). The $K$ variable indicates factors that can adversely impact marriage wage premium through researchers' decision to report a statistically significant coefficient to get published. In most meta-regression analysis, the $K$ variable indicates a dummy variable, but it can affect multicollinearity (Stanley and Doucouliagos, 2012). However, which variables should be used as these $Z$ and $K$ variables? Because there is a debate in the literature, and it depends on the type of data at hand. In this analysis, the identified $Z$ variables are year dummies (sixties, seventies, eighties, nineties, and thousand), model specification variables (Fixed-Effect, OLS), data type (NLSY data or not and US data or not) and structure of dependent variable used as marriage wage premium (dummy variable for log of the hourly wage) affect the reported wage premium. The identified $Z$-variables are divided by the standard error, $\mathrm{Se}$ (recall Equation 6).

Table 4 presents the empirical findings that are estimated by using the multivariate MRA model with added $\mathrm{Z}$ and $\mathrm{K}$ variables (Equation 6). The estimations are based on a 'general to specific' (GTS) approach in which the above variables were included in a meta-regression analysis, and the insignificant variables were omitted, one at a time. Column 1 reports the estimated MRA results using robust standard errors and other alternative methods, including clustered data analysis, Random- 
Effects Multilevel (REML), and robust regression analysis, respectively, in columns 3,4 , and 5. REML method is very important because, within study dependence, is a potential problem in meta-regression. After including the variables, genuine effects

Table 4: Multivariate MRA Model, General-to-Specific

\begin{tabular}{|c|c|c|c|c|c|c|c|c|}
\hline $\begin{array}{c}\text { Moderator } \\
\text { Variables }\end{array}$ & \multicolumn{2}{|c|}{$\begin{array}{l}\text { Column 1: } \\
\text { WLS }\end{array}$} & \multicolumn{2}{|c|}{$\begin{array}{l}\text { Column 2: } \\
\text { Clustered data } \\
\text { analysis }\end{array}$} & \multicolumn{2}{|c|}{$\begin{array}{l}\text { Column 3: } \\
\text { REML }\end{array}$} & \multicolumn{2}{|c|}{$\begin{array}{c}\text { Column 4: } \\
\text { Robust }\end{array}$} \\
\hline \multicolumn{9}{|c|}{ Genuine Empirical Effects (Z-Variables) } \\
\hline$(1 / \mathrm{Se})$ & -0.079 & {$[-4.86]$} & -0.079 & {$[-5.80]$} & -0.079 & {$[-5.37]$} & -0.081 & [-6.34] \\
\hline $\begin{array}{l}\text { D_two } \\
\text { thousand/Se }\end{array}$ & 0.079 & [8.69] & 0.079 & [8.04] & 0.079 & [7.29] & 0.054 & [3.12] \\
\hline D_Fixed-Effect/Se & -0.022 & {$[-2.57]$} & -0.022 & {$[-4.03]$} & -0.022 & {$[-1.89]$} & -0.015 & {$[-1.52]$} \\
\hline D_OLS/Se & 0.037 & [4.22] & 0.037 & [4.35] & 0.037 & [4.38] & 0.047 & [6.16] \\
\hline D_US data/Se & 0.060 & [3.89] & 0.060 & [4.54] & 0.060 & [4.64] & 0.050 & [4.37] \\
\hline $\begin{array}{l}\text { D_log of the } \\
\text { hourly wage /Se }\end{array}$ & -0.023 & {$[-3.21]$} & -0.023 & {$[-3.38]$} & -0.023 & {$[-3.12]$} & 0.013 & [0.76] \\
\hline \multicolumn{9}{|c|}{ Publication Bias (K-Variables) } \\
\hline O_urbun/rural & -5.819 & {$[-3.40]$} & -5.819 & {$[-2.20]$} & -5.819 & {$[-4.37]$} & -5.049 & {$[-4.41]$} \\
\hline O_female age & 8.776 & [4.38] & 8.776 & {$[5.58]$} & 8.776 & {$[5.21]$} & 8.843 & [6.10] \\
\hline O_different age & 6.731 & [4.64] & 6.731 & [4.25] & 6.731 & [4.95] & 5.516 & [4.71] \\
\hline $\begin{array}{l}\text { O_female } \\
\text { education }\end{array}$ & -9.973 & {$[-5.44]$} & -9.973 & {$[-7.36]$} & -9.973 & {$[-3.59]$} & 2.714 & [1.75] \\
\hline $\begin{array}{l}\text { O_worker } \\
\text { education }\end{array}$ & 4.714 & [2.94] & 4.714 & {$[2.37]$} & 4.714 & [4.29] & 3.469 & [3.61] \\
\hline $\begin{array}{l}\text { O_years of } \\
\text { divorced }\end{array}$ & -4.874 & {$[-3.24]$} & -4.874 & {$[-3.94]$} & -4.874 & {$[-4.10]$} & -5.157 & {$[-5.04]$} \\
\hline O_region & 2.235 & {$[2.73]$} & 2.235 & {$[2.26]$} & 2.235 & {$[3.26]$} & 1.790 & [3.03] \\
\hline O_union/nonunion & 3.411 & [2.97] & 3.411 & [2.39] & 3.411 & [3.54] & 3.305 & [3.99] \\
\hline O_years of married & 2.824 & {$[2.87]$} & 2.824 & {$[5.58]$} & 2.824 & {$[3.55]$} & 2.192 & [3.17] \\
\hline $\begin{array}{l}\text { O_female } \\
\text { occupation } \\
\text { public/private }\end{array}$ & 18.256 & [4.39] & 18.256 & [8.14] & 18.256 & {$[5.36]$} & - & \\
\hline $\begin{array}{l}\text { O_years of job } \\
\text { experience }\end{array}$ & -1.914 & {$[-2.40]$} & -1.914 & {$[-1.94]$} & -1.914 & {$[-2.63]$} & -0.970 & {$[-1.51]$} \\
\hline _cons & -17.701 & {$[-3.62]$} & -17.701 & {$[-5.43]$} & -17.701 & {$[-5.71]$} & 11.478 & {$[-4.31]$} \\
\hline R-squared & & 0.630 & & 0.630 & & 0.630 & - & \\
\hline $\mathrm{N}$ & & 106 & & 106 & & 106 & & 104 \\
\hline
\end{tabular}

Notes: Dependent variable: reported t-statistics and all regressions relate to Equation 6. $t$-values are reported in parenthesis except columns 4 because REML (random-effects multi-level model) estimates are in z-value and are calculated from robust standard errors. " $D$ " indicates the dummy variable, and "O" indicates the omitted variable. 
(heterogeneity) can be identified by the combination of $\mathrm{Z}$ variables (variables are divided by $\mathrm{Se}$ ), and publication biases are now captured by $\mathrm{K}$ variables (variables are not divided by $\mathrm{Se}$ ) along with the intercept. After including all the variables that are selected for $\mathrm{Z}$ and $\mathrm{K}$ variables (31 coded variables: See appendix 1); D_two thousand/Se, D_Fixed-Effect/Se, D_OLS/Se, D_US data/Se, D_log of the hourly wage /Se for the $\mathrm{Z}$ variables and O_urbun/rural, O_female age, O_different age, O_female education, O_worker education, O_years of divorced, O_region, O_union/non-union, O_years of married, O_female occupation public/private, O_years of job experience for the $\mathrm{K}$ variables are the only significant variables that affect the marriage wage premium. That implies those variables are most important to estimate the marriage wage premium. However, the most important findings that I want to emphasize are the existence of publication bias and the absence of a genuine effect on marriage wage premium, which remains after including $\mathrm{Z}$ and $\mathrm{K}$ variables.

\section{Publication Selection}

To check for publication bias, we can use a jointly statistically significant test for the combination of $\mathrm{K}$ variables with the intercept (because the intercept does not indicate the magnitude of publication bias itself). There is clear evidence of publication bias in this multivariate MRA because $\mathrm{F}(10,87)=5.58(\mathrm{p}<.0001)$ and the calculated average estimated publication bias for the marriage wage literature is 6.66 (summation of all $\mathrm{k}$ variables coefficient with intercept). It is higher than the simple MRA model that accounts for 3.48 (See column 2 Table 2).

The negative omitted factors associated with publication bias are urban or rural, female education, years of divorce, and years of job experience. When defined as benchmarks of study, variables other than what was mentioned above, such as, female age, worker different age, education, union or non-union, years of marriage and female occupation public or private, have a positive impact and do not omit the estimate of marriage wage equation. Other than that, the only differences, which are whether the spouse is employed in public/ private sector (O_female occupation public/private), no longer exist in the robust method in columns 4 .

\section{Genuine Effect of the Married Wage Premium}

The genuine effect can be identified by using $\mathrm{Z}$ variables: D_two thousand/Se, D_Fixed-Effect/Se, D_OLS/Se, D_US data/Se, D_log of the hourly wage /Se. Thus, the marriage wage premium is a combination of coefficients of $Z$ variables. Hence, all of these $\mathrm{Z}$ variables are zero; the estimated marriage premium indicates a positive effect, which accounts for 0.068 with approximately is $6.8 \%$ in the robust method (0.058 for the WLS method with approximately $5.8 \%$ ). This is much higher than the 
simple MRA model that is used for Table 2 in Equation 2, which accounts for 0.022. Together, these $\mathrm{Z}$ variables represent the genuine positive marriage wage premium with statistical significance, $F(6,87)=18.42 ; \mathrm{p}<0.001$. This positive marriage premium is due to the period from 2000 to 2009 (D_two thousand/Se), which estimates coefficient to increase by 0.079 (using the WLS) and using U.S. data (D_US data/Se), which is an increase by 0.060 . Moreover, the estimated technique of the OLS method has a positive impact on wage premium ( 0.047 by robust in column 4$)$. At the same time, there is a negative impact from the natural log of the hourly wage (D_log of the hourly wage /Se), which is -0.023 .

\section{Conclusion}

A systematic and comprehensive meta-analysis of a male marriage wage premium from research literature finds a meaningful impact on wage. It accounts for $6.8 \%$ with evidence of publication bias after applying descriptive statistics, funnel graph, simple meta-regression analysis (MRA), and multiple MRAs of 120 estimated coefficients. However, it is hard to correct the identified publication bias, and its effects on the marriage premium, because of heteroskedasticity among reported econometric estimates of the marriage premium. The simple MRA method detects the publication bias and leads to testing for genuine effect beyond the publication bias. However, after applying the MRA model of the precision-effect estimate with standard error (PEESE), which reduces the bias, the estimated marriage premium is approximately about $2 \%$ (0.018). Finally, multivariate meta-regression models are applied to the empirical literature on estimated marriage premium.

The method used for estimating genuine marriage premium by controlling publication bias is proof that the genuine effect exists while failing to reject the publication bias. The detected publication bias is also evidenced by the funnelasymmetry test. Thus, the average estimated publication bias accounted for $6.6 \%$. However, the genuine marriage wage effect is much higher than the simple MRA model. Finally, all the estimation techniques confirm that hard to control publication bias exists among marriage premiums. However, it is much harder to control this publication bias, resulting from the nature of empirical research in social science. Thus, it is important to clarify and filter the publication bias from any summary of empirical findings to provide clear evidence of research results.

\section{Declaration of Conflicting Interests}

The author declared no potential conflicts of interest with respect to the research, authorship, and publication of this article. 


\section{References}

Ashenfelter, O., Harmon, C., \& Oosterbeek, H. (1999). A review of estimates of the schooling/earnings relationship, with tests for publication bias. Labour Economics, 6(4), 453-470. https://doi.org/10.1016/S0927-5371(99)00041-X

Ahituv, A., \& Lerman, R. I. (2007). How do marital status, work effort, and wage rates interact?. Demography, 44(3), 623-647.

https://doi.org/10.1353/dem.2007.0021

Antonovics, K., \& Town, R. (2004). Are all the good men married? Uncovering the sources of the marital wage premium. American Economic Review, 94(2), 317 321. https://www.jstor.org/stable/3592902

Baaijens, S. R., Nijkamp, P., \& Van Montfort, K. (1998). Explanatory meta-analysis for the comparison and transfer of regional tourist income multipliers. Regional Studies, 32(9), 839-849. https://doi.org/10.1080/00343409850117997

Bardasi, E., \& Taylor, M. (2008). Marriage and wages: A test of the specialization hypothesis. Economica, 75(299), 569-591. https://doi.org/10.1111/j.14680335.2007.00630.x

Becker, G. S. (1981). A treatise on the family. Harvard University Press

Blackburn, M., \& Korenman, S. (1994). The declining marital-status earnings differential. Journal of Population Economics, 7(3), 247-270. https://www.jstor.org/stable/20007436

Button, K. (1995). Road pricing as an instrument in traffic management. In B. Johansson \& L.G. Mattson (Eds.), Road pricing: Theory, empirical assessment and policy (pp. 35-55). Springer, Dordrecht.

Button, K., \& Kerr, J. (1996). The effectiveness of traffic restraint policies: A simple meta-regression analysis. Rivista Internazionale di Economia dei Trasporti [International Journal of Transport Economics] 213-225. https://www.jstor.org/stable/42747424

Card, D., Mas, A., Moretti, E., \& Saez, E. (2012). Inequality at work: The effect of peer salaries on job satisfaction. American Economic Review, 102(6), 29813003. https://www.aeaweb.org/articles?id=10.1257/aer.102.6.2981

Card, D., \& Krueger, A. B. (1995). Myth and measurement. Princeton University Press.

Chiodo, A. J., \& Owyang, M. T. (2002). For love or money: why married men make more. The Regional Economist. Federal Reserve Bank of St. Louis.

Chun, H., \& Lee, I. (2001). Why do married men earn more: Productivity or marriage selection? Economic Inquiry, 39(2), 307-319. https://doi.org/10.1111/j.1465-7295.2001.tb00068.x 
Choudhury, S. (2002). Racial and ethnic differences in wealth holdings and portfolio choices (No. 95). Social Security Administration, Office of Research, Evaluation, and Statistics.

Cohen, Y., \& Haberfeld, Y. (1991). Why do married men earn more than unmarried men?. Social Science Research, 20(1), 29-44. https://doi.org/10.1016/0049089X(91)90002-K

Cornwell, C., \& Rupert, P. (1997). Unobservable individual effects, marriage and the earnings of young men. Economic Inquiry, 35(2), 285-294. https://doi.org/10.1111/j.1465-7295.1997.tb01910.x

de Linde Leonard, M., \& Stanley, T. D. (2015). Married with children: What remains when observable biases are removed from the reported male marriage wage premium. Labour Economics, 33, 72-80. https://doi.org/10.1016/j.labeco.2015.02.010

Disdier, A. C., \& Head, K. (2008). The puzzling persistence of the distance effect on bilateral trade. The Review of Economics and Statistics, 90(1), 37-48.

Doucouliagos, C. (1997). The aggregate demand for labour in Australia: A metaanalysis. Australian Economic Papers, 36(69), 224-242. https://doi.org/10.1111/j.1467-8454.1997.tb00847.x

Doucouliagos, C., \& Ulubasoglu, M. A. (2006). Economic freedom and economic growth: Does specification make a difference?. European Journal of Political Economy, 22(1), 60-81. https://doi.org/10.1016/j.ejpoleco.2005.06.003

Doucouliagos, H., \& Stanley, T. D. (2009). Publication selection bias in minimumwage research? A meta-regression analysis. British Journal of Industrial Relations, 47(2), 406-428. https://doi.org/10.1111/j.1467-8543.2009.00723.x

Doucouliagos, C., Stanley, T. D., \& Giles, M. (2012). Are estimates of the value of a statistical life exaggerated? Journal of health economics, 31(1), 197-206. https://doi.org/10.1016/j.jhealeco.2011.10.001

Dougherty, C. (2006). The marriage earnings premium as a distributed fixed effect. Journal of Human Resources, 41(2), 433-443. https://www.jstor.org/stable/40057282

Duval, S., \& Tweedie, R. (2000). A nonparametric "trim and fill" method of accounting for publication bias in meta-analysis. Journal of the American Statistical Association, 95(449), 89-98. https://doi.org/10.1080/01621459.2000.10473905

Egger, M., Smith, G. D., Schneider, M., \& Minder, C. (1997). Bias in meta-analysis detected by a simple, graphical test. BMJ, 315(7109), 629-634. https://doi.org/10.1136/bmj.315.7109.629 
Espey, M. (1996). Explaining the variation in elasticity estimates of gasoline demand in the United States: A meta-analysis. The Energy Journal, 17(3). https://doi.org/10.5547/ISSN0195-6574-EJ-Vol17-No3-4

Espey, M. (1998). Gasoline demand revisited: An international meta-analysis of elasticities. Energy Economics, 20(3), 273-295.

https://doi.org/10.1016/S0140-9883(97)00013-3

Ginther, D. K., \& Zavodny, M. (2001). Is the male marriage premium due to selection? The effect of shotgun weddings on the return to marriage. Journal of Population Economics, 14(2), 313-328. https://www.jstor.org/stable/20007764

Gorg, H., \& Strobl, E. (2001). Multinational companies and productivity spillovers: A meta-analysis. The Economic Journal, 111(475), 723-739. https://www.jstor.org/stable/798312

Gorman, E. H. (1999). Bringing home the bacon: Marital allocation of incomeearning responsibility, job shifts, and men's wages. Journal of Marriage and the Family, 61(1), 110-122. https://doi.org/10.2307/353887

Gray, J. S. (1997). The fall in men's return to marriage: Declining productivity effects or changing selection? Journal of Human Resources, 32(3) 481-504. https://doi.org/10.2307/146180

Hamermesh, D. S., \& Biddle, J. E. (1993). Beauty and the labor market (No. w4518). National Bureau of Economic Research.

Hersch, J., \& Stratton, L. S. (1997). Housework, fixed effects, and wages of married workers. Journal of Human Resources, 285-307. https://doi.org/10.2307/146216

Hersch, J., \& Stratton, L. S. (2000). Household specialization and the male marriage wage premium. Industrial and Labor Relations Review, 54(1), 78-94. https://doi.org/10.2307/2696033

Indika, N. (2018). Does marriage affect men's labor market outcomes? A semiparametric longitudinal analysis. Journal of International and Global Economic Studies, 11(1)

Jacobsen, J. P., \& Rayack, W. L. (1996). Do men whose wives work really earn less? The American Economic Review, 86(2), 268-273. https://www.jstor.org/stable/2118135

Jarrell, S. B., \& Stanley, T. D. (1990). A meta-analysis of the union-nonunion wage gap. Industrial \& Labor Relations Review, 44(1), 54-67. https://doi.org/10.2307/2523429

Korenman, S., \& Neumark, D. (1991). Does marriage really make men more productive? Journal of Human Resources, 26(2), 282-307. https://doi.org/10.2307/145924 
Lerman, R. I. (2002). Married and unmarried parenthood and the economic wellbeing offamilies: A dynamic analysis of a recent cohort. The Urban Institute.

Loh, E. S. (1996). Productivity differences and the marriage wage premium for white males. Journal of Human Resources, 31(3),566-589. https://www.jstor.org/stable/146266

Loomis, J. B., \& White, D. S. (1996). Economic benefits of rare and endangered species: Summary and meta-analysis. Ecological Economics, 18(3), 197-206. https://doi.org/10.1016/0921-8009(96)00029-8

Ludwig, V., \& Brüderl, J. (2018). Is there a male marital wage premium? New evidence from the United States. American Sociological Review, 83(4), 744770. http://journals.sagepub.com/doi/abs/10.1177/0003122418784909

McConnell, B., \& Valladares-Esteban, A. (2021). On the marriage wage premium.

McDonald, P. (2020). The male marriage premium: Selection, productivity, or mployer preferences? Journal of Marriage and Family, 82(5), 1553-1570. https://doi.org/10.1111/jomf.12683

Matters, W. M. (2005). Twenty-six conclusions from the social sciences. Institute for American Values.

Maasoumi, E., Millimet, D. L., \& Sarkar, D. (2009). Who benefits from marriage?. Oxford Bulletin of Economics and Statistics, 71(1), 1-33.

McManus, P. A., \& DiPrete, T. A. (2001). Losers and winners: The financial consequences of separation and divorce for men. American Sociological Review, 246-268. https://doi.org/10.2307/2657417

Nakosteen, R. A., \& Zimmer, M. A. (1987). Marital status and earnings of young men: A model with endogenous selection. Journal of Human Resources, 22(2)248-268. https://doi.org/10.2307/145904

Nakosteen, R. A., \& Zimmer, M. A. (1997). Men, money, and marriage: Are high earners more prone than low earners to marry? Social Science Quarterly, 78(1), 66-82. https://www.jstor.org/stable/42863675

Phillips, J. M. (1994). Farmer education and farmer efficiency: A metaanalysis. Economic Development and Cultural Change, 43(1), 149-165. https://www.jstor.org/stable/1154336

Phillips, J. M., \& Goss, E. P. (1995). The effect of state and local taxes on economic development: A meta-analysis. Southern Economic Journal, 320-333. https://doi.org/10.2307/1060685

Rose, A. K., \& Stanley, T. D. (2005). A meta-analysis of the effect of common currencies on international trade. Journal of Economic Surveys, 19(3), 347-365. https://doi.org/10.1111/j.0950-0804.2005.00251.x 
Schoeni, R. F. (1995). Marital status and earnings in developed countries. Journal of Population Economics, 8(4), 351-359. https://doi.org/10.1007/BF00180873

Stanley, T. D. (2001). Wheat from chaff: Meta-analysis as quantitative literature review. The Journal of Economic Perspectives, 15(3), 131-150. https://www.jstor.org/stable/2696560

Stanley, T. D. (2005). Beyond publication bias. Journal of Economic Surveys, 19(3), 309-345. https://doi.org/10.1111/j.0950-0804.2005.00250.x

Stanley, T. D. (2008). Meta-regression methods for detecting and estimating empirical effects in the presence of publication selection. Oxford Bulletin of Economics and statistics, 70(1), 103-127. https://doi.org/10.1111/j.14680084.2007.00487.x

Stanley, T. D., \& Doucouliagos, H. (2007). Identifying and correcting publication selection bias in the efficiency-wage literature: Heckman meta-regression (Working Paper, Economics Series, No. 11). School of Accounting, Economics and Finance, University of Deakin.

Stanley, T. D., \& Doucouliagos, H. (2012). Meta-regression analysis in economics and business. Routledge.

Stanley, T. D., \& Jarrell, S. B. (1989). Meta-regression analysis: A quantitative method of literature surveys. Journal of Economic Surveys, 3(2), 161-170. https://doi.org/10.1111/j.1467-6419.1989.tb00064.x

Smith, V. K., \& Kaoru, Y. (1990). Signals or noise? Explaining the variation in recreation benefit estimates. american Journal of Agricultural Economics, 72(2), 419-433. https://doi.org/10.2307/1242344

Waite, L. J. (1995). Does marriage matter?. Demography, 32(4), 483-507. https://doi.org/10.2307/2061670

Weitzman, M. L., \& Kruse, D. L., (1990). Profit sharing and productivity. In. A. S. Blinder (Ed.), Paying for productivity: A look at the evidence (Studies in defence policy) (pp. 95-142). 


\section{Appendix 1 Selected Meta-Articles}

Waite, L. J. (1995)

1490

Korenman, S., \& Neumark, D. (1991)

1001

Gray, J. S. (1997)

Hersch, J., \& Stratton, L. S. (1997)

Loh, E. S. (1996)

Hersch, J., \& Stratton, L. S. (2000)

Chun, H., \& Lee, I. (2001) 298

Antonovics, K., \& Town, R. (2004) 256

Ginther, D. K., \& Zavodny, M. (2001) 200

Cornwell, C., \& Rupert, P. (1997) 186

Nakosteen, R. A., \& Zimmer, M. A. (1987) 168

Schoeni, R. F. (1995) 148

Ahituv, A., \& Lerman, R. I. (2007) 146

Dougherty, C. (2006) 143

Choudhury, S. (2002) 141

Bardasi, E., \& Taylor, M. (2008) 118

Jacobsen, J. P., \& Rayack, W. L. (1996) 111

Maasoumi, E., Millimet, D. L., \& Sarkar, D. (2009) 85

Cohen, Y., \& Haberfeld, Y. (1991) 43

Note: Citations are based on Google Scholar in January 2020 
Appendix 2: Meta-Independent Variables

\begin{tabular}{|c|c|c|c|c|c|}
\hline \multicolumn{2}{|c|}{ Dependent Variable } & \multicolumn{2}{|c|}{ Measurement of DV } & \multicolumn{2}{|c|}{ Other Demographic Characters } \\
\hline Var & Variable Description & Var & Variable Description & Var & Variable Description \\
\hline $\begin{array}{l}\text { Estearning } \\
\text { (estimated } \\
\text { effect) }\end{array}$ & Estimated wage premium & $\begin{array}{l}\text { lnofho } \\
\text { url ge }\end{array}$ & $\begin{array}{l}1 \text { if the dependent variable in the } \\
\text { regression was the natural } \\
\text { log of the hourly wage }\end{array}$ & $\begin{array}{l}\text { oyears } \\
\text { ofma } \\
\text { d }\end{array}$ & $\begin{array}{l}1 \text { if the study omitted the } \\
\text { number of years that the } \\
\text { respondent had been married }\end{array}$ \\
\hline \multicolumn{2}{|c|}{ Model and data } & $\begin{array}{l}\text { hourlyc } \\
\text { ons } \sim \mathrm{d}\end{array}$ & $\begin{array}{l}1 \text { if a study used hourly wages } \\
\text { computed from daily, weekly, } \\
\text { monthly, or annual salary }\end{array}$ & $\begin{array}{l}\text { oyears } \\
\text { ofdi d d }\end{array}$ & $\begin{array}{l}1 \text { if the study omitted the } \\
\text { number of years that the } \\
\text { respondent was divorced }\end{array}$ \\
\hline so & $\begin{array}{l}\text { standard error of the } \\
\text { estimated marriage-wage } \\
\text { premium }\end{array}$ & $\begin{array}{l}\text { annual } \\
\text { wages }\end{array}$ & 1 if a study used annual earnings & okids & $\begin{array}{l}\text { if the study omitted whether or } \\
\text { not the worker has children }\end{array}$ \\
\hline sixties & $\begin{array}{l}1 \text { if the data was from the } \\
\text { time period } 1960-1969\end{array}$ & Job & & $\begin{array}{l}\text { omarit } \\
\text { alki n }\end{array}$ & $\begin{array}{l}1 \text { if a study omitted interaction } \\
\text { children }\end{array}$ \\
\hline seveties & $\begin{array}{l}1 \text { if the data was from the } \\
\text { time period } 1970-1979\end{array}$ & $\begin{array}{l}\text { opublic } \\
\text { sec } \sim \mathrm{r}\end{array}$ & $\begin{array}{l}1 \text { if a study omitted the wages of } \\
\text { workers in the public sector only }\end{array}$ & $\begin{array}{l}\text { whiteo } \\
\text { nly }\end{array}$ & $\begin{array}{l}1 \text { if the sample was restricted to } \\
\text { white men only }\end{array}$ \\
\hline eighties & $\begin{array}{l}1 \text { if the data was from the } \\
\text { time period } 1980-1989\end{array}$ & $\begin{array}{l}\text { oprivat } \\
\text { ese } \sim \mathrm{r}\end{array}$ & $\begin{array}{l}1 \text { if a study omitted the wages of } \\
\text { workers in the private sector only }\end{array}$ & $\begin{array}{l}\text { wasdiv } \\
\text { orced }\end{array}$ & $\begin{array}{l}1 \text { if the study is omitted } \\
\text { whether the worker was } \\
\text { divorced }\end{array}$ \\
\hline nineties & $\begin{array}{l}1 \text { if the data was from the } \\
\text { time period 1990-1999 }\end{array}$ & $\begin{array}{l}\text { onarro } \\
\text { wocc } ~ \\
\mathrm{n}\end{array}$ & $\begin{array}{l}1 \text { if a study omitted the wages of } \\
\text { workers of a narrowly } \\
\text { defined occupation }\end{array}$ & $\begin{array}{l}\text { oworke } \\
\text { rage }\end{array}$ & $\begin{array}{l}1 \text { if the study omitted the } \\
\text { workers age }\end{array}$ \\
\hline twothousand & $\begin{array}{l}1 \text { if the data was from the } \\
\text { time period } 2000-2009\end{array}$ & $\begin{array}{l}\text { ounion } \\
\text { nonu } \sim \mathrm{s}\end{array}$ & $\begin{array}{l}1 \text { if a study omitted workers } \\
\text { union/non-union status }\end{array}$ & $\begin{array}{l}\text { odiffer } \\
\text { en ge }\end{array}$ & $\begin{array}{l}1 \text { if the study omitted the } \\
\text { workers different age stages }\end{array}$ \\
\hline fixe & $\begin{array}{l}1 \text { if the study used fixed } \\
\text { effects estimation }\end{array}$ & $\begin{array}{l}\text { oindust } \\
\text { ryo } \sim \mathrm{t}\end{array}$ & $\begin{array}{l}1 \text { if a study omitted worker's } \\
\text { industry of employment }\end{array}$ & $\begin{array}{l}\text { oworke } \\
\text { redu n }\end{array}$ & $\begin{array}{l}1 \text { if the study omitted the } \\
\text { workers educational level }\end{array}$ \\
\hline
\end{tabular}




\begin{tabular}{|c|c|c|c|c|c|}
\hline \multicolumn{2}{|c|}{ Dependent Variable } & \multicolumn{2}{|c|}{ Measurement of DV } & \multicolumn{2}{|c|}{ Other Demographic Characters } \\
\hline Var & Variable Description & Var & Variable Description & Var & Variable Description \\
\hline re & $\begin{array}{l}1 \text { if the study used random } \\
\text { effects estimation }\end{array}$ & $\begin{array}{l}\text { oworki } \\
\text { ngtime }\end{array}$ & $\begin{array}{l}1 \text { if the study omitted the worker's } \\
\text { age }\end{array}$ & $\begin{array}{l}\text { ourbun } \\
\text { rural }\end{array}$ & 1 if a study omitted urban \\
\hline ols & $\begin{array}{l}1 \text { if the study used OLS } \\
\text { estimation }\end{array}$ & $\begin{array}{l}\text { oselfe } \\
\text { mplo d }\end{array}$ & $\begin{array}{l}1 \text { if the study omitted the worker's } \\
\text { as self employed }\end{array}$ & orace & 1 if a study omitted the race \\
\hline gls & $\begin{array}{l}1 \text { if the study used OLS } \\
\text { estimation }\end{array}$ & $\begin{array}{l}\text { oyears } \\
\text { ofj ce }\end{array}$ & $\begin{array}{l}1 \text { if the study omitted the worker's } \\
\text { years of job experience }\end{array}$ & $\begin{array}{l}\text { oregio } \\
\mathrm{n}\end{array}$ & 1 if a study omitted the region \\
\hline dnlsy & $\begin{array}{l}1 \text { if the study used data from } \\
\text { NISY }\end{array}$ & \multicolumn{2}{|c|}{ Spouse characteristics } & $\begin{array}{l}\text { oreligi } \\
\text { on }\end{array}$ & 1 if a study omitted the religion \\
\hline dusdata & $\begin{array}{l}1 \text { if the study used data from } \\
\text { USA }\end{array}$ & $\begin{array}{l}\text { ofemal } \\
\text { esin } \sim \mathrm{n}\end{array}$ & $\begin{array}{l}1 \text { if the study omitted the spouse } \\
\text { occupation }\end{array}$ & $\begin{array}{l}\text { oworke } \\
\text { rwas } \sim \mathrm{n}\end{array}$ & $\begin{array}{l}1 \text { if the study omitted whether } \\
\text { the worker was a Veteran }\end{array}$ \\
\hline \multirow[t]{5}{*}{ dpanaldata } & 1 if the study used Panel data & $\begin{array}{l}\text { ofoccu } \\
\text { pati v }\end{array}$ & $\begin{array}{l}1 \text { if the study omitted the spouse } \\
\text { occupation as public/private sector }\end{array}$ & $\begin{array}{l}\text { tenureo } \\
\text { nth } \sim \mathrm{b}\end{array}$ & $\begin{array}{l}1 \text { if the study omitted the } \\
\text { worker's tenure with his } \\
\text { current employer }\end{array}$ \\
\hline & & $\begin{array}{l}\text { ofemal } \\
\text { eedu n n }\end{array}$ & $\begin{array}{l}1 \text { if the study omitted the spouse } \\
\text { education }\end{array}$ & & \\
\hline & & $\begin{array}{l}\text { ofemal } \\
\text { eage }\end{array}$ & 1 if the study omitted the spouse age & & \\
\hline & & $\begin{array}{l}\text { ofemal } \\
\text { ewage }\end{array}$ & $\begin{array}{l}1 \text { if the study omitted the spouse } \\
\text { wage }\end{array}$ & & \\
\hline & & $\begin{array}{l}\text { onoohh } \\
\text { ours } \sim \mathrm{m}\end{array}$ & $\begin{array}{l}1 \text { if the study omitted the spouse no } \\
\text { of hours in working }\end{array}$ & & \\
\hline
\end{tabular}

